\title{
Thyroid Function Tests in Children with Cystic Fibrosis: Is Thyroid Dysfunction more Common than Estimated in These Patients?
}

\author{
Kistik Fibrosisli Çocuklarda Tiroid Fonksiyon Testleri: Tiroid \\ Disfonksiyonu Bu Hastalarda Tahmin Edilenden Daha mı Fazla?

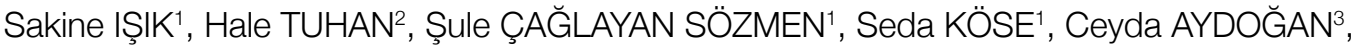

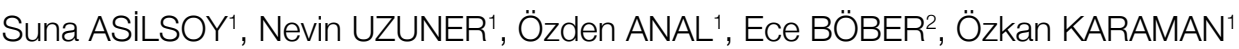

${ }^{1}$ Dokuz Eylül University, Faculty of Medicine, Department of Pediatric Allergy and Immunology, İzmir, Turkey

${ }^{2}$ Dokuz Eylül University, Faculty of Medicine, Department of Pediatric Endocrinology, İzmir, Turkey

${ }^{3}$ Dokuz Eylül University, Faculty of Medicine, Department of Pediatrics, İzmir, Turkey

\begin{abstract}
Objective: Cystic fibrosis (CF) is a life-limiting, multisystemic, autosomal recessive genetic disorder that is characterized by digestive and respiratory dysfunction contributing to growth deficit, chronic respiratory infections, progressive lung tissue damage, and premature death. CF patients have several important endocrine abnormalities including exocrine pancreatic insufficiency, poor linear growth, bone diseases, hypogonadism and thyroid dysfunction. In the present study, we aimed to investigate the prevalence of thyroid dysfunction in children with CF and evaluate the general characteristics of these patients in Turkey.

Material and Methods: The study was conducted between January 2015 and June 2015. A total of 42 patients (20 male, 22 female) with CF were included in the study. Demographic information; clinical, laboratory and radiological findings; medication use, and genetic analyses were assessed from the medical records. The serum fT4, fT3 and TSH levels were measured by chemiluminescence immunoassay using a DxI800 autoanalyzer (Beckman Coulter Inc., CA, USA).

Results: The mean age at the time of diagnosis of CF was 35.5 $\pm 53.2(2-194)$ months in the study population. Eight of the 42 (19\%) patients whose TSH, fT4 and fT3 levels were measured had abnormal TSH and fT4 levels (two overt hypothyroidism and six subclinical hypothyroidism). Five (62.5\%) of the subjects with thyroid dysfunction were receiving thyroid hormone replacement therapy.

Conclusion: Our study presents the first evaluation of the patients with CF for thyroid dysfunction in Turkey. In our study population, we detected eight (19\%) CF patients with thyroid dysfunction and five (62.5\%) of them were receiving L-thyroxine treatment. In our opinion, regular evaluation of thyroid function tests in patients with CF may be necessary to prevent problems associated with hypothyroidism.
\end{abstract}

Key Words: Children, Cystic fibrosis, L-thyroxine, Thyroid dysfunction

\section{ÖZ}

Amaç: Kistik fibrozis progresif akciğer hasarı, kronik solunum yolu enfeksiyonları, büyüme geriliği ve erken ölüme neden olan sindirim ve solunum disfonksiyonu ile karakterize multistemik, hayatı kısıtlayan, otozomal resesif genetik bir hastalıktır. Kistik fibrozis ekzokrin panreatik yetmezlik, büyüme geriliği, kemik hastalıkları, hipogonodism ve tiroid hastalıklarını kapsayan bazı önemli endokrin anormalliklere neden olabilmektedir. Bu çalışmada amaç, kistik fibrozisli çocuklarda tiroid disfonksiyonu prevelansını araștırmak ve bu hastaların genel karakteristiklerini belirlemektir.

Gereç ve Yöntemler: Çalışma, Ocak 2015-Haziran 2015 tarihleri arasında yapılmıştır. Toplam 42 kistik fibrozisli hasta (20 erkek, 22 kız) çalışmaya alınmıştır. Demografik, klinik, laboratuvar ve radyolojik bulgular, ilaç kullanımı, genetik analizler dosya kayıtlarından elde edilmiştir. Serum fT4, fT3 ve TSH düzeyleri kemilüminesans immunoassay yöntemiyle DxI800 autoanalyzer (Beckman Coulter Inc, CA, USA) kullanılarak ölçülmüştür.

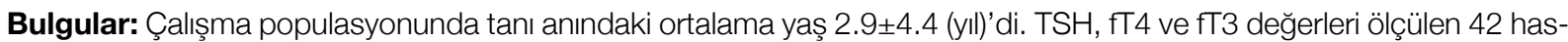
tanın 8 tanesi (\%19) anormal TSH ve Ft4 düzeyine (2 aşikar hipotroidi, 6 subklinik hipotoridi) sahipti. Tiroid disfonksiyonu olan hastaların 5 tanesi (\%62.5) tiroid hormon replasman tedavisi almaktaydı.

Sonuç: Çalışmamızda ilk defa Türkiye'de kistik fibrozisli hastalar tiroid disfonksiyonu açısından değerlendirilmiştir. Çalışma populasyonumuzda tiroid disfonksiyonu olan 8 (\%19) hasta saptadık ve bunların 5 tanesi (\% 62.5) L-tiroksin tedavisi almaktaydı. Kistik fibrozisli hastalarda hipotiroidi ile ilişkili problemleri önlemek amacıyla düzenli tiroid fonksiyon testleri değerlendirmesinin bu hastalarda gerekli olduğu kanaatindeyiz.

Anahtar Sözcükler: Çocuk, Kistik fibrosis, L-Tiroksin, Tiroid disfonksiyonu 


\section{INTRODUCTION}

Cystic fibrosis (CF) caused by single genetic defect which encodes the cystic fibrosis transmembrane conductance regulator (CFTR), a chloride channel that is widely located in epithelial surfaces (1). The epithelium in the airways, pancreatic ducts, gut, bile ducts, vas deferens, sweat channels and thyroid expresses CFTR (2,3). Defects in CFTR function in these organs give rise to lung infections, bronchiectasis, progressive respiratory failure; exocrine pancreatic insufficiency with malabsorption; episodic intestinal obstruction; liver disease and male infertility. In addition, patients with CF have many important endocrine abnormalities, such as CF-associated diabetes, inadequate linear growth, bone diseases, hypogonadism and thyroid dysfunction (4).

An increased incidence of goiter with or without associated hypothyroidism as a complication of receiving pulmonary expectorants containing iodides, low T3 and/or low T 4 and rT 3 levels with increased basal and $\mathrm{TRH}$-stimulated $\mathrm{TSH}$ levels, impaired peripheral conversion of T4 to T3 due to selenite deficiency as a result of malnutrition have been reported in particular in patients with CF in previous studies (5-8). However, unlike previously published studies, normal thyroid function tests in patients with CF compared with normal healthy subjects is available in the literature (9). In present study, we aimed to investigate the prevalence of thyroid dysfunction in children with CF (i) and evaluate general characteristics of these patients in Turkey (ii).

\section{MATERIALS and METHODS}

A total of 42 patients with CF aged between 2 months and 16.1 years who had been attending our outpatient clinic between 2011 and 2015 were enrolled in the study. The diagnosis of CF was confirmed in all patients by genetic analysis and the sweat test. The age of onset of complaints, sex, body weight $\mathrm{SD}$, height SD, laboratory findings (including infections, sweat test, genetic analysis of CTFR gene, respiratory function test), radiological findings (including pulmonary computed tomography, thyroid ultrasonography), and thyroid hormone or pancreatic enzyme replacement therapy of all subjects were retrospectively recorded from the medical records.

The serum $\mathrm{fT} 4$ and TSH levels were measured using DxI800 autoanalyzer (Beckman Coulter Inc, CA, USA) with chemiluminescence immunoassay method. The lower and upper limit values of the measurement method used in the biochemistry laboratory were considered the normal reference range for thyroid function tests (fT4: 0.5-1.51 ng/dL, fT3: 2.5-5.5 $\mathrm{pg} / \mathrm{ml}) \mathrm{TSH}$ : 0.34-5.6 ulU/L). The subjects whose serum TSH and fT4 levels were within the normal limits were considered euthyroid, the subjects whose fT4 level was low and TSH level was 5.6-20 $\mathrm{\mu lU} / \mathrm{mL}$ or $>20 \mu \mathrm{lU} / \mathrm{mL}$ were considered to have overt hypothyroidism, and the subjects whose fT4 was normal and TSH was 5.6-20 $\mu \mathrm{lU} / \mathrm{mL}$ were considered to have subclinical hypothyroidism. Serum anti-TPO and anti- TG levels were measured with the chemiluminescence immunoassay method using Immulite 2500 autoanalyzer (Siemens Healthcare Diagnostics, Erlangen, Germany). The normal reference range was considered 0-9 $\mathrm{lU} / \mathrm{mL}$ for anti-TPO and 0-4 $\mathrm{U} / \mathrm{mL}$ for antiTG. All thyroid function tests were obtained from the patients during the absence of clinical and laboratory findings of infections to exclude the effect of inflammation on thyroid fuction tests. The thyroid volume was calculated on thyroid ultrasonography using the following formula: width $x$ length $\times 0.523$. Values above the 97th percentile were considered to indicate goiter (10). All patients (above 7 years) underwent pulmonary function tests using spirometry. Forced expiratory volume in 1 second (FEV1) was documented. All pulmonary function tests were performed according to the European Respiratory Society consensus standards by the same technician (11).

Approval was obtained from Dokuz Eylül University School of Medicine Non-invasive Research Ethics Committee for the study (Decision number: 2014/38-10).

The data was recorded in SPSS for Windows v.16 (SPSS, Inc., Chicago, IL,USA). The Mann-Whitney U-test and X2 or Fisher's exact test were used to compare the numerical and categorical variables, respectively, between two groups. $\mathrm{p}<0.05$ was considered significant.

\section{RESULTS}

Twenty-two (52.3\%) females and 20 (47.7\%) males were included in the study. The mean age at the time of diagnosis of CF was $35.5 \pm 53.2(2-194)$ months. Of the 42 patients who underwent the sweat test, 31 (73.8\%) of the subjects had a sweat chloride value greater than $60 \mathrm{mmol} / \mathrm{L}$. The most frequent genetic mutation of the CTFR gene was Phe508del but we could not determine any genetic mutation by CFTR genetic analysis in $11(26.1 \%)$ of the subjects. The mean body weight SD was $-1.3 \pm 1.71$, and the mean height SD was $-0.7 \pm 1.5$. Thirty-nine (92.8\%) of the subjects had exogenous pancreatic insufficiency that required enzyme replacement. None of the patients were treated with iodine-containing drugs. Renal and liver function tests, total serum protein levels and fasting blood glucose levels were normal in the patients. Thirty-one (73.8\%) and 25 (59.5\%) subjects had Pseudomonas aeruginosa and Staphylococcus aureus colonization, respectively. Demographic and laboratory characteristics of the whole patient group are shown in Table I.

\section{Results of patients with thyroid dysfunction $(n=8)$}

There were 8 (19\%) subjects with abnormal serum thyroid function tests. Five (62.5\%) of the CF patients with thyroid dysfunction group were in the infant age group. When 6 (75\%) of the subjects were assessed for subclinical hypothyroidism, 2 
(25\%) of the subjects had overt hypothyroidism. Five (62.5\%) of the subjects with abnormal serum thyroid function test received 1-2 mcg/kg/day L-thyroxine treatment. Goiter was not observed on physical examination. Anti-TPO and Anti-TG antibody, fT3 levels and thyroid ultrasonography were normal in all of the subjects. The available serum TSH, fT4, fT3 and Anti-TPO, Anti-TG values are presented in Table 2. The most common genetic mutation was Phe508del $(37.5 \%, \mathrm{n}=3)$ in subjects with thyroid dysfunction. Six (75\%) and $3(37.5 \%)$ of the subjects had Pseudomonas aeruginosa and Staphylococcus aureus colonization, respectively. Only one subject had bronchiectasis. Six $(75 \%)$ of the subjects had a history of hospitalization at least once.

There was no significant correlation between weight and height SD and thyroid hormone values.

All of the subjects had exogenous pancreatic insufficiency and received pancreatic enzyme replacement.

There was no significant difference for mean weight and height $\mathrm{SD}$, colonization of Pseudomonas aeruginosa and Staphylo-

Table I: Demographic and laboratory characteristics of the whole patient group.

\begin{tabular}{|c|c|}
\hline Age of diagnosis, months & $35.4 \pm 52.6(3-172)$ \\
\hline $\begin{array}{l}\text { Sex } \\
\quad \text { Male } \\
\text { Female }\end{array}$ & $\begin{array}{l}23(51.1 \%) \\
22(48.8 \%)\end{array}$ \\
\hline Weight SD & $-1.25 \pm 1.73$ \\
\hline Height SD & $-0.67 \pm 1.5$ \\
\hline FEV1,\% $(n=21)$ & $61(49-126)$ \\
\hline TSH, $\mu$ IU/MI & $3.47 \pm 3.6(0.93-20.0)$ \\
\hline fT4, ng/dL & $1.06 \pm 0.24(0.47-1.57)$ \\
\hline fT3, ng/dL & $3.7 \pm 0.87(2.5-5.9)$ \\
\hline $\begin{array}{l}\text { Pancreatic enzyme replacement } \\
\text { Yes } \\
\text { No }\end{array}$ & $\begin{array}{c}41(91.1 \%) \\
4(8.9 \%)\end{array}$ \\
\hline $\begin{array}{l}\text { Thyroid Hormone replacement } \\
\text { Yes } \\
\text { No }\end{array}$ & $\begin{array}{r}5 \text { (11.1\%) } \\
40 \text { (88.9\%) }\end{array}$ \\
\hline $\begin{array}{l}\text { Sweat test }(\mathbf{n}=\mathbf{4 4}) \\
\text { High } \\
\text { Doubtful } \\
\text { Normal }\end{array}$ & $\begin{array}{l}31(70.4 \%) \\
8(18.1 \%) \\
5(11.5 \%)\end{array}$ \\
\hline $\begin{array}{l}\text { CTFR gene analysis } \\
\text { Positive } \\
\text { Negative }\end{array}$ & $\begin{array}{l}31 \text { (68.9\%) } \\
14(31.1 \%)\end{array}$ \\
\hline $\begin{array}{l}\text { Bronchiectasis } \\
\text { Yes } \\
\text { No }\end{array}$ & $\begin{array}{l}10(22.2 \%) \\
35(77.8 \%)\end{array}$ \\
\hline Ps. aeruginosa Colonization & $31(68.9 \%)$ \\
\hline Staph. aureus Colonization & 25 (55.6\%) \\
\hline
\end{tabular}

coccus aureus, exogenous pancreatic insufficiency, and history of hospitalization between the patients with or without thyroid dysfunction ( $p>0.05)$.

In the follow-up, patients with overt hypothyroidism continue to receive $L$-Thyroxine treatment at dose of $1-2 \mathrm{mcg} / \mathrm{kg} / \mathrm{day}$. Two of the patients with subclinical hypothyroidism also continue to receive treatment due to development of overt hypothyroidism. In one of the patients with subclinical hypothyroidism, treatment was discontinued due to normalization of the tests during follow-up.

Demographic characteristics, laboratory and radiological findings of the CF patients with thyroid dysfunction are summarized in Table II.

\section{DISCUSSION}

Cystic fibrosis is a common life-limiting autosomal recessive genetic disorder. It is caused by the mutation of a gene that encodes a chloride-conducting transmembrane channel called the cystic fibrosis transmembrane conductance regulator (CFTR), which is widely distributed in epithelial surfaces (12). The epithelium in the airways, paranasal sinuses, pancreatic ducts, gut, bile duct, vas deferens, and sweat channels express CFTR and depend on it for normal function (13). Important comorbidities caused by epithelial cell dysfunction give rise to lung infection and bronchiectasis, leading to progressive respiratory impairment; pancreatic insufficiency with malabsorption; episodic intestinal obstruction; liver disease and male infertility (14).

During the past six decades, the median age of survival has increased progressively, and is now more than 40 years in developed countries $(15,16)$. With increasing age, the prevalence of endocrine complications such as cystic fibrosis related diabetes (CFRD), cystic fibrosis related bone diseases, short stature, vitamin D deficiency, hypogonadism, adrenal disorders and hypothyroidism are gradually increasing. In present study, we aimed to investigate the prevalence of thyroid dysfunction in children with CF (i) and evaluate general characteristics of these patients in Turkey (ii). In our study, we detected eight (19\%) CF patients with thyroid dysfunction and five $(62.5 \%$ ) of the subjects with thyroid dysfunction were receiving L-thyroxine treatment.

Several authors have postulated goiter and hypothyroidism in CF patients since the 1970s. However, the mechanism for the development of hypothyroidism in these patients with $\mathrm{CF}$ is not clear yet. There are several possible explanations for the development of hypothyroidism in patients with CF. Hypothyroidism and goiter in CF patients were first reported by Dolan et al. as complications of iodide overload due to the widespread use of iodine-containing pulmonary expectorants (5). The findings by Dolan et al. have been replicated by Azizi et al. (17), and they showed that $44 \%$ of CF patients given high- 
Table II: Demographic characteristics, laboratory and radiological findings of the CF patients with thyroid dysfunction.

\begin{tabular}{|c|c|c|c|c|c|c|c|c|}
\hline Patients & $\begin{array}{c}1 \\
(\mathrm{BK})\end{array}$ & $\begin{array}{c}2 \\
\text { (NŞ) }\end{array}$ & $\begin{array}{c}3 \\
\text { (TS) }\end{array}$ & $\begin{array}{c}4 \\
\text { (NŞ) }\end{array}$ & $\begin{array}{c}5 \\
\text { (MVE) } \\
\end{array}$ & $\begin{array}{c}6 \\
(\mathrm{NK})\end{array}$ & $\begin{array}{c}7 \\
\text { (FE) }\end{array}$ & $\begin{array}{c}8 \\
\text { (AMD) }\end{array}$ \\
\hline Age at diagnosis (month) & 48 & 6 & 56 & 4 & 33 & 3 & 2 & 12 \\
\hline Sex (Male/Female) & M & $\mathrm{F}$ & $\mathrm{F}$ & $\mathrm{F}$ & M & $\mathrm{F}$ & M & M \\
\hline Weight SD & 1.2 & -3.5 & -3.3 & -0.8 & 1.1 & -2.2 & -2.6 & -6 \\
\hline Height SD & 1.1 & -2.5 & -1.9 & -0.6 & 1.2 & -2.4 & -1.5 & -5 \\
\hline FT3 (pg/ml) & 4.40 & 3.25 & 3.99 & 4.13 & 4.71 & 3.72 & 4.34 & 2.5 \\
\hline fT4 (ng/dl) & 1.01 & 0.65 & 1.23 & 1.64 & 1.37 & 0.47 & 1.28 & 1.07 \\
\hline TSH $(\mu \mathrm{lU} / \mathrm{mL})$ & 5.95 & 11.34 & 7.14 & 8.21 & 5.02 & 20.0 & 8.03 & 6.52 \\
\hline CTFR gene analysis & Negative & $\begin{array}{l}\text { Delta } \\
\text { f } 508\end{array}$ & $\begin{array}{l}\text { Delta } \\
\text { f } 508\end{array}$ & Negative & V470m & Negative & $\begin{array}{l}\text { Delta } \\
\text { f } 508\end{array}$ & Negative \\
\hline Sweat test $(\mu \mathrm{mol} / \mathrm{mL})$ & 81 & 64 & 62 & 104 & 66 & 71 & - & 124 \\
\hline FEV1,\% & 80 & - & - & - & 95 & - & 102 & - \\
\hline Thyroid Ultrasonography & Normal & Normal & Normal & Normal & Normal & Normal & Normal & Normal \\
\hline $\begin{array}{l}\text { Thyroid Hormone replacement } \\
\text { (Yes/No) }\end{array}$ & No & Yes & Yes & Yes & No & Yes & No & Yes \\
\hline $\begin{array}{l}\text { Pancreatic Enzyme Replacement } \\
\text { (Yes/No) }\end{array}$ & Yes & Yes & Yes & Yes & Yes & Yes & Yes & Yes \\
\hline $\begin{array}{l}\text { History of hospitalization } \\
\text { (Yes/No) }\end{array}$ & Yes & Yes & No & Yes & No & Yes & Yes & Yes \\
\hline $\begin{array}{l}\text { Bronchiectasis } \\
\text { (Yes/No) }\end{array}$ & No & No & No & No & No & Yes & No & No \\
\hline $\begin{array}{l}\text { Ps. aeruginosa Colonization } \\
\text { (Yes/No) }\end{array}$ & Yes & Yes & Yes & Yes & No & Yes & No & Yes \\
\hline $\begin{array}{l}\text { Staph. aureus Colonization } \\
\text { (Yes/No) }\end{array}$ & No & No & Yes & Yes & No & No & Yes & No \\
\hline
\end{tabular}

dose iodine developed goiter, and $83 \%$ of those developed hypothyroidism.

One of the proposed mechanisms for the development of hypothyroidism in CF patients is altered ion transport in thyroid epithelium, as seen in CFTR-deficient pigs. In this knockout animal model, there were no changes in thyroid histology, growth pattern, or sodium-iodide symporter expression, but there was diminished cAMP-activated chloride secretion, an ion that may act as a counter-ion for iodine accumulation, leading to disruption of iodine accumulation in the thyroid (18).

Naehrlich et al. have demonstrated a high prevalence of subclinical hypothyroidism (11.6\%) and iodine deficiency (83.7\%) in patients with $\mathrm{CF}$, that was unrelated to age, malnutrition or pulmonary function. In this study, they suggested that relatively low iodine dietary intake, reduced iodine absorption due to pancreatic insufficiency, and high iodine loss through sweat could explain the high prevalence of iodine deficiency in the CF population (19).

Another possible explanation for the hypothyroidism is impaired peripheral T4 conversion to T3 related to selenium deficiency
(20). Selenium regulates the expression of deiodinase isoenzymes and in particular type 1,5 - deiodinase has been described to have low activity in CF patients, and selenium replacement has been reported to increase T3 levels and as well as a decreased $\mathrm{T} 4 / \mathrm{T} 3$ ratio indicating an improved peripheral conversion of T4 to T3 in CF patients (8). One of the limitations of our study is that iodine and selenium status could not be determined. However, all of our patients had pancreatic insufficiency and almost all of them received enteral nutritional supplements that included selenium and iodine. None of our patients received iodine-containing drugs. We therefore did not consider selenium or iodine deficiency in our patient group.

The prevalence of underlying thyroid dysfunction in patients with CF remains controversial, with some studies reporting normal thyroid function while others found subclinical hypothyroidism. A recent study by Volta et al. (9) suggested no significant thyroid dysfunction in $17 \mathrm{CF}$ patients compared to age- and sex-matched controls, and they concluded that this may be related to improved nutritional status and lack of iodine including pulmonary expectorant use. The largest study assessing thyroid dysfunction in patients with CF was presented by Sun 
et al. (21). In this study, a total of 89 subjects were included in the analyses. Although 24 (27\%) of the patients had abnormal serum thyroid function tests, overt thyroid dysfunction was rare in this cohort of 89 patients with CF. In this study, the authors reported that there was no significant predictor of thyroid dysfunction such as age, sex, race, BMI (Body Mass Index), FEV1, hospitalization status, recent antibiotic use or use of pancreatic enzyme replacement (21).

The diagnosis of CF can be easily made in almost all cases with a combination of sweat chloride concentration and/or genetic analysis. Sweat chloride values of $60 \mathrm{mmol} / \mathrm{L}$ or greater are diagnostic for CF, whereas values of 40 to $59 \mathrm{mmol} / \mathrm{L}$ for individuals 6 months of age or older and values 30 to 59 $\mathrm{mmol} / \mathrm{L}$ for infants under the age of 6 months warrant further evaluation with CFTR mutation analysis (22). There are six classes of mutations of the CFTR gene $(23,24)$. Although wide phenotypic variation exists among individuals with the same genotype, patients who have 2 alleles from classes I-III most often have early manifestation of pancreatic insufficiency and more severe pulmonary disease than patients with mutation classes $\mathrm{V}$ and $\mathrm{VI}$ in which there may be some small residual amount of CFTR function (24). Phe508del, a class II mutation, is the most common CF mutation. In our study population the most frequent CFTR mutation was, Phe508del ( $n=13,30.9 \%$ ), similar to the literature. Three of the CF patients with thyroid dysfunction had Phe508del mutation, and thirty-one had greater than $60 \mathrm{mmol} / \mathrm{L}$ sweat chloride values.

Pulmonary manifestations include persistent infections with typical CF pathogens, such as Staphylococcus aureus, nontypeable Hemophilus influenzae and Pseudomonas aeruginosa. In our study, three (37.5 \%) and five $(62.5 \%)$ of the CF patients with thyroid dysfunction had Staphylococcus aureus and Pseudomonas aeruginosa colonization, respectively.

Growth impairment in CF can be observed in infants from the age of 6 weeks and is more severe during adolescence (25). Early treatment of suboptimal growth in CF is recommended (26). Inadequate dietary intake due to anorexia together with malabsorption due to pancreatic insufficiency, and the increased energy demand, chronic inflammation, and treatment with inhaled and systemic glucocorticoid medications all contribute to linear growth retardation in patients with CF (27). CF-related diabetes and hypothyroidism also contribute to this condition (28). In our study, three of the CF patients with thyroid dysfunction had linear growth retardation but there was no significant correlation between height SD and thyroid hormone values. In our opinion, when growth failure is identified in patients with CF, treatable causes such as thyroid dysfunction should be considered.

In conclusion, we detected eight (19\%) CF patients with thyroid dysfunction in our study population and five of them were receiving L-thyroxine treatment. Our study presents the first assessment of the CF patients for thyroid dysfunction in Turkey. In our opinion, regular evaluation of thyroid function in
CF patients may be necessary to prevent problems associated with hypothyroidism. However, these results need to be confirmed by larger series.

\section{REFERENCES}

1. Riordan JR, Rommens JM, Kerem B, Alon N, Rozmahel R, Grzelczak Z, et al. Identification of the cystic fibrosis gene: Cloning and characterization of complementary DNA. Science 1989; 245:1066-73.

2. Davis PB. Cystic fibrosis since 1938. Am J Respir Crit Care Med 2006;173:475-82.

3. Devuyst O, Golstein PE, Sanches MV, Piontek K, Wilson PD, Guggino WB, et al. Expression of CFTR in human and bovine thyroid epithelium. Am J Physiol 1997;272:1299-308.

4. Blackman SM, Tangpricha V. Endocrine disorders in cystic fibrosis. Pediatr Clin North Am 2016;63:699-708.

5. Dolan TF, Gibson LE. Complications of iodine therapy in patients with cystic fibrosis. J Pediatr 1971;79:684-7.

6. Segall-Blank M, Vagenakis AG, Shwachman $H$, Ingbar $\mathrm{SH}$, Braverman LE. Thyroid gland function and pituitary TSH reserve in patients with cystic fibrosis. J Pediatr 1981;98:218-22.

7. De Luca F, Trimarchi F, Sferlazzas C, Benvenga S, Costante G, Mami $\mathrm{C}$, et al. Thyroid function in children with cystic fibrosis. Eur $\mathrm{J}$ Pediatr 1982;138:327-30.

8. Kauf E, Dawczynski H, Jahreis G, Janitzky E, Winnfeld K. Sodium selenite therapy and thyroid hormone status in cystic fibrosis and congenital hypothyroidism. Biol Trace Elem Res 1994;40:247-53.

9. Volta C, Street ME, Ziveri MA, Bonelli P, Spaggiari C, Grzincich GL, et al. Thyroid function, cytokine and IGF-IGFBP interactions in cystic fibrosis patients. Horm Res 2005;63:206-10.

10. Tas F, Bulut S, Egilmez H, Oztoprak I, Ergur AT, Candan F. Normal thyroid volume by ultrasonography in healthy children. Ann Trop Paediatr 2002; 22: 375-9.

11. Miller MR, Hankinson J, Brusasco V, Burgos F, Casaburi R, Coates A, et al. Standardisation of spirometry. Eur Respir J 2005; 26:31938.

12. Kelly T, Buxbaum J. Gastrointestinal manifestations of cystic fibrosis. Dig Dis Sci 2015;60:1903-13.

13. Gelfond D, Borowitz D. Gastrointestinal complications of cystic fibrosis. Clin Gastroenterol Hepatol 2013;11:333-42.

14. J Stuart Elborn. Cystic fibrosis. Lancet 2016;388:2519-31.

15. Elborn JS, Shale DJ, Britton JR. Cystic fibrosis: Current survival and population estimates to the year 2000. Thorax 1991;46:8815.

16. Burgel PR, Bellis G, Olesen HV, Viviani L, Zolin A, Blasi F, et al. Future trends in cystic fibrosis demography in 34 European countries. Eur Respir J 2015;46:133-41.

17. Azizi F, Bentley D, Vagenakis A, Portnay G, Bush JE, Shwachman $\mathrm{H}$, et al. Abnormal thyroid function and response to iodides in patients with cystic fibrosis. Trans Assoc Am Physicians 1974; 87:111-9.

18. Li H, Ganta S, Fong P. Altered ion transport by thyroid epithelia from CFTR(-/-) pigs suggests mechanisms for hypothyroidism in cystic fibrosis. Exp Physiol 2010;95:1132-44.

19. Naehrlich L, Dörr H-G, Bagheri-Behrouzi A, Rauh M. lodine deficiency and subclinical hypothyroidism are common in cystic fibrosis patients. J Trace Elem Med Biol 2013;27:122-5. 
20. Kohrle J. Thyroid hormone deiodinases - A selenoenzyme family acting as gate keepers to thyroid hormone action. Acta Med Austriaca 1996;23:17-30.

21. Lee SY, Chesdachai S, Lee MJ, He XM, Tangpricha V, Braverman LE. Thyroid function in patients with cystic fibrosis: No longer a concern? Thyroid 2016;26:875-9.

22. Farrell $P$, Rosenstein B, White T, Accurso FJ, Castellani C, Cutting $\mathrm{GR}$, et al. Guidelines for diagnosis of cystic fibrosis in newborns through older adults. J Pediatr 2008;153:4-14.

23. Rogan M, Stoltz D, Hornick D. Cystic fibrosis transmembrane conductance regulator intracellular processing, trafficking, and opportunities for mutation-specific treatment. Chest 2011;139:1480-90.

24. Castellani C, Cuppens H, Macek M, Cassiman JJ, Kerem E, Durie $\mathrm{P}$, et al. Consensus on the use and interpretation of cystic fibrosis mutation analysis in clinical practice. J Cyst Fibros 2008;7:179-96.
25. Hardin DS. Growth problems and growth hormone treatment in children with cystic fibrosis. J Pediatr Endocrinol Metab 2002;15:731-5.

26. Stark LJ, Quittner AL, Powers SW, Opopari-Arrigan L, Bean JA, Duggan $C$, et al. Randomized clinical trial of behavioral intervention and nutrition education to improve calorie intake and weight in children with cystic fibrosis. Arch Pediatr Adolesc Med 2009;163: 915-21.

27. Scaparrotta A, Di Pillo S, Attanasi M, Consilvio NP, Cingolani A, Rapino D, et al. Growth failure in children with cystic fibrosis. J Pediatr Endocrinol Metab 2012; 25:393-405.

28. Leonard A, Davis E, Rosenstein BJ, Zeitlin PL, Paranjape SM, Peeler D, et al. Description of a standardized nutrition classification plan and its relation to nutritional outcomes in children with cystic fibrosis. J Pediatr Psychol 2010;35:6-13. 